\title{
Do Genomic Factors Play a Role in Diabetic Retinopathy?
}

\author{
Andrea P. Cabrera ${ }^{1}$, Finny Monickaraj ${ }^{1,2}$, Sampathkumar Rangasamy ${ }^{3}{ }^{\circ}$, Sam Hobbs ${ }^{1}{ }^{1}$, \\ Paul McGuire ${ }^{4}$ and Arup Das ${ }^{1,2,4, *}$ \\ 1 Department of Surgery/Ophthalmology, University of New Mexico School of Medicine, Albuquerque, \\ NM 87131, USA; apcabrera@salud.unm.edu (A.P.C.); fmonickaraj@salud.unm.edu (F.M.); \\ sdhobbs@gmail.com (S.H.) \\ 2 New Mexico VA Health Care System, Albuquerque, NM 87131, USA \\ 3 Translational and Genomics Research Institute (TGen), Phoenix, AZ 85004, USA; srangasamy@tgen.org \\ 4 Department of Cell Biology \& Physiology, UNM, Albuquerque, NM 87131, USA; pmcguire@salud.unm.edu \\ * Correspondance: adas@unm.edu
}

Received: 9 December 2019; Accepted: 9 January 2020; Published: 14 January 2020

\begin{abstract}
Although there is strong clinical evidence that the control of blood glucose, blood pressure, and lipid level can prevent and slow down the progression of diabetic retinopathy (DR) as shown by landmark clinical trials, it has been shown that these factors only account for $10 \%$ of the risk for developing this disease. This suggests that other factors, such as genetics, may play a role in the development and progression of DR. Clinical evidence shows that some diabetics, despite the long duration of their diabetes ( 25 years or more) do not show any sign of DR or show minimal non-proliferative diabetic retinopathy (NPDR). Similarly, not all diabetics develop proliferative diabetic retinopathy (PDR). So far, linkage analysis, candidate gene studies, and genome-wide association studies (GWAS) have not produced any statistically significant results. We recently initiated a genomics study, the Diabetic Retinopathy Genetics (DRGen) Study, to examine the contribution of rare and common variants in the development of different phenotypes of DR, as well as their responsiveness to anti-VEGF treatment in diabetic macular edema (DME). Our preliminary findings reveal a novel set of genetic variants involved in the angiogenesis and inflammatory pathways that contribute to DR progression or protection. Further investigation of variants can help to develop novel biomarkers and lead to new therapeutic targets in DR.
\end{abstract}

Keywords: diabetic retinopathy; genetics; GWAS; whole exome sequencing; blood-retinal barrier; VEGF

\section{Introduction}

Diabetic retinopathy (DR) is a microvascular complication of diabetes that involves blood-retinal barrier alteration, inflammation, and neuronal dysfunction [1-3]. According to the 2017 International Diabetes Federation Atlas, about 425 million people have diabetes mellitus in the world, and by 2045 this number is projected to reach 629 million [4]. With $35 \%$ of the diabetic population afflicted, DR is the most common cause of blindness among middle-aged working adults [5]. Duration of diabetes is the strongest predictor for the progression of DR. Interestingly, some diabetics do not develop DR at all, or only develop mild DR (few microaneurysms), in spite of a long duration of diabetes [6]. Similarly, not all diabetics develop the sight-threatening phenotype of diabetic macular edema (DME) or proliferative diabetic retinopathy (PDR) [7-11]. Furthermore, the response to anti-VEGF (vascular endothelial growth factor) drugs in DME patients is variable, with only $27-45 \%$ patients responding well ( $>15$ letters of vision improvement) [12]. The variability in phenotype of DR and anti-VEGF treatment responsiveness in DME suggests a potential role for other factors in the development of DR. 
Several risk factors have been associated with the prevalence of DR. Large-scale epidemiological studies revealed that duration of diabetes, hyperglycemia, hypertension and hyperlipidemia are the major risk factors associated with this disease (see Table 1) [7,13-18]. Although there is strong clinical evidence supporting the role of blood glucose, blood pressure, and lipid level in controlling the slow progression of DR (Diabetes Control and Complications Trial [DCCT], United Kingdom Prospective Diabetes Study [UKPDS], Action to Control Cardiovascular Risk in Diabetes [ACCORD]) [14-21] the Wisconsin Epidemiologic Study of Diabetic Retinopathy (WESDR) showed that hemoglobin A1C, cholesterol and blood pressure only account for $10 \%$ of the risk for developing retinopathy [22]. Furthermore, a follow-up statistical analysis of the Diabetes Control and Complications Trial (DCCT) revealed that the glycemic exposure (duration of diabetes, $\mathrm{HbA} 1 \mathrm{C}$ level) explains only $11 \%$ of the decrease in retinopathy risk [23]. Other factors, genetic and/or environmental, may explain the remaining $89 \%$ of the variation in retinopathy risk [23]. Together, these observations suggest that genetic factors may play a role in the development and progression of DR.

Table 1. Risk Factors Associated with Prevalence of Diabetic Retinopathy.

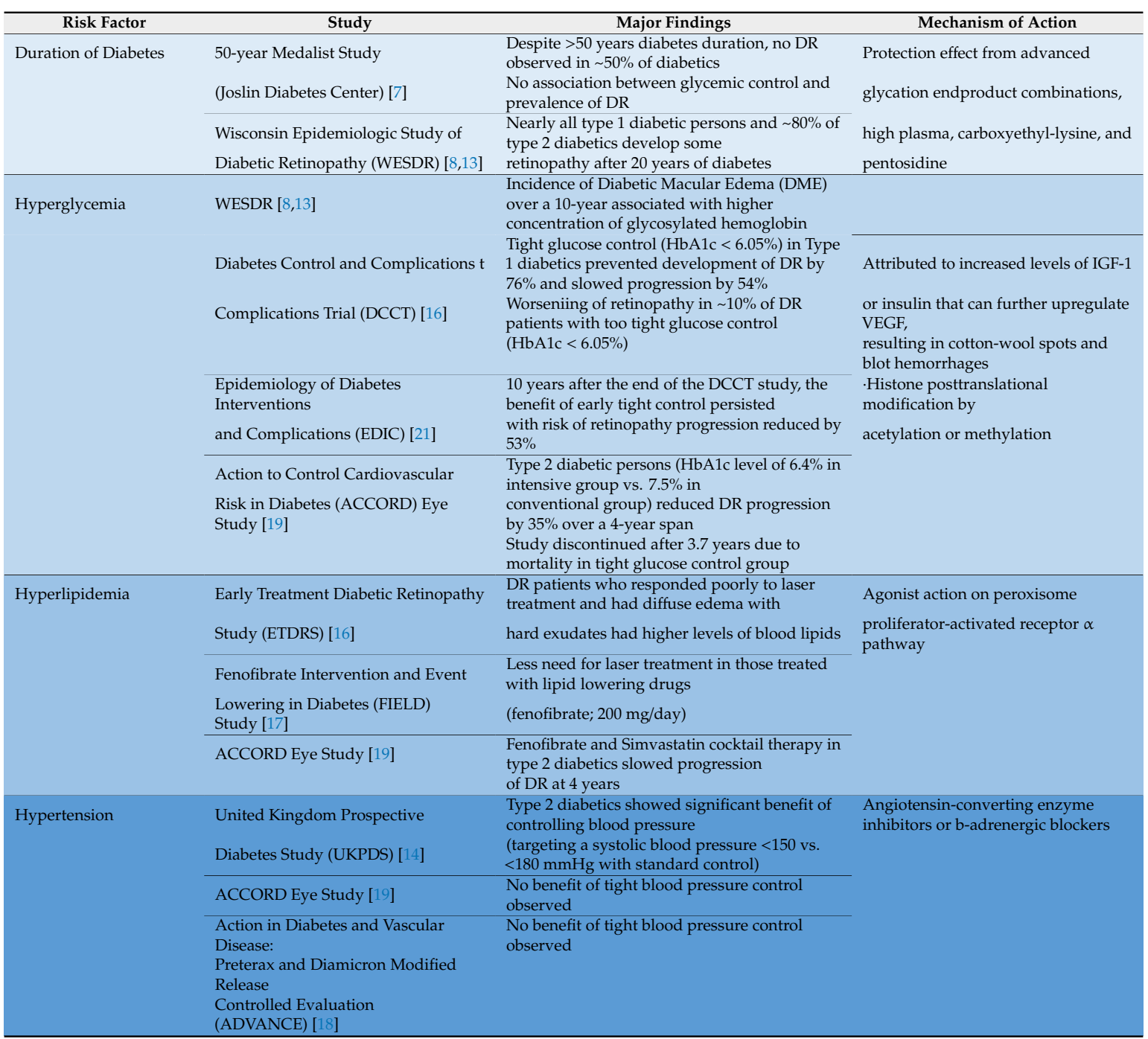

Mechanistic studies have identified four major hyperglycemia-induced biochemical pathways associated with DR (polyol, advanced glycation end products, protein kinase C, and hexosamine). These pathways have been shown to lead to detrimental downstream cascading events (oxidative stress, inflammation, and vascular dysfunction) [24]. Despite the success in identifying these biochemical mechanisms and the ability of pharmacological interventions to block these pathways in animal models, 
these therapeutic strategies have not proven to be efficacious in human clinical trials. Based on these experimental and clinical outcomes, it has become critical to explore alternative factors which may be involved in the development of DR.

\section{Role of Genetics in DR}

Since the introduction of hereditary transmission by Gregor Mendel, the field of genetics has flourished tremendously [25]. Rapid developments in technology have set the stage for gene mapping and the investigation of numerous disease-associated genetic variants. What started as simple observations in pea plants has evolved into sophisticated methods for investigating the genetic components of complex, multifactorial diseases such as DR [26,27].

Familial clustering studies have consistently shown the involvement of genetics in DR. Early observations of non-insulin-dependent diabetic twins revealed 95\% agreement in the degree of severity of this disease [28,29]. Additionally, the DCCT study has shown that diabetic first-degree family members of study subjects who progressed to severe non-proliferative diabetic retinopathy (NPDR) or PDR had a risk ratio of 3.1 for progression compared with those study subjects who did not have such progression [30]. Furthermore, differences in the frequency and severity of DR have long been observed among different ethnic populations [31-33]. Together these studies provide evidence in support of the role of genetics in DR. Thus, in this review, we discuss (1) the current understanding of DR genetics and (2) assess recent key studies. Lastly, we propose strategies to address the challenges of previous studies with the goal of furthering insight into the underlying genetic architecture of DR.

Although the role of genetics in DR is well recognized, the precise gene variant(s) underlying this disease remain elusive. While studies have identified many DR-associated genetic variants, only a few have been replicated. However, these confirmatory studies have all resulted in weak associations. Thus, it is likely that these results are indicative of the elaborate disease mechanisms underlying DR. Revisiting previous studies may help in understanding the pitfalls as well developing new strategies to further understand the genetics of DR.

\section{Heritability and Linkage Analysis}

Early studies of sibling pairs have long established the role of genetics in DR. Linkage analyses have provided a foundational method that relies on the physical proximity of non-random associations of alleles of chromosomal mutations to identify disease-associated links [34-36]. Thus far, this method has had a long history of success in the identification of variants in monogenic diseases [37-39]. However, success in elucidating the role of genetics in complex diseases, including DR, has been arduous $[40,41]$.

To date, cohorts of Pima Indians and Mexican Americans have been studied for DR-associated linkages [42-44]. However, these studies have yielded varying results. Interestingly, no common linkage regions were identified in two separate analyses of Pima Indians, despite examination of the same cohort. [42,43]. While one study with Pima Indians demonstrated linkage in the same chromosomal region (1p36) as the Mexican American cohort, the threshold suggestive of linkage by conventional criteria (Logarithm of Odds score > 3.3) was not met. [42-44].

While these studies provided strong evidence for genetic contribution in this disease, the lack of reproducibility of the identified DR-associated linkages may be indicative of the involvement of additional factors. The genetic understanding of DR presents a unique challenge because of the etiological mechanisms involved. While DR is recognized as a complex multifactorial disease, understanding disease pathogenesis is further complicated by virtue of retinopathy being a mere, but detrimental, complication of another complex disease (diabetes) [45,46]. To address this challenge, several approaches have been utilized to understand the underlying role of genetics in DR. 


\section{Candidate Gene Association Studies}

Candidate gene association is an epidemiologic approach frequently used to understand the pathological processesinvolved in disease [47]. In contrast to gene mapping methods, in which the precise location of genes on the chromosome can be linked to disease, candidate gene association relies on hypothesis-driven inferences with an emphasis on pathological observations [48,49]. Supported, but limited, by clinical observations and biochemical pathway knowledge, this approach provides a practical method for the identification of genetic variants. To date, many candidate genes have been associated with DR: vascular endothelial growth factor (VEGF), hypoxia-inducible factor 1-alpha (HIF1A), and erythropoietin (EPO) genes [50-53]. Additionally, several glucose metabolism, vascular tone, blood pressure regulation, and inflammatory-associated genes have been identified (receptor for advanced glycation end product (RAGE), aldose reductase (AKR1B1), glucose transporter 1 (SLC2A1), angiotensin-1 converting enzyme (ACE), nitric oxide synthase 3 (NOS3), and intracellular adhesion molecule-1 (ICAM1)) [51,53,54]. However, these studies have yielded variable results. These candidate genes have been previously reviewed elsewhere $[55,56]$. Importantly, the Candidate gene Association Resource (CARe) study showed that, among 39 genes known to be associated with DR or diabetes, three single nucleotide polymorphisms in P-selectin were associated with DR [57]. None of the genes reported in the candidate gene studies have been replicated in other cohorts. Here, we highlight the vascular endothelial growth factor (VEGF) gene because of its therapeutic success.

\section{Vascular Endothelial Growth Factor}

The importance of VEGF in ocular neovascularization was first established in studies of laser-induced hypoxia in non-human primate models [58]. These studies revealed elevated levels of VEGF in aqueous fluid that correlated with the severity of neovascularization. This key finding has since made VEGF a strong proponent in the development of DR [59]. The role of VEGF was further confirmed when clinical observations revealed elevated VEGF levels in the vitreous and aqueous fluid of DR patients [60]. To date, several genetic studies have identified various VEGF polymorphisms associated with DR [50,61,62]. However, these studies have produced variable results [51,57,63].

The putative role of VEGF in ocular neovascularization led to adaptation of anti-VEGF therapies for the treatment of DR [64]. Interestingly, despite the success of anti-VEGF in restoring visual acuity in PDR patients, success has been limited in DR patients with diabetic macular edema (DME), [65] indicating the possible influence of genetic polymorphisms. In a recent study, VEGF polymorphism C634G was identified as a genetic risk factor for DME and its presence resulted in a 'good response' outcome to anti-VEGF therapy [66]. However, VEGF polymorphism C634G as a pharmacogenetic marker has yet to be confirmed in follow-up studies. Additionally, it should be noted that VEGF polymorphism C634G has yielded varying results among different population groups [67-69]. While the candidate gene association approach has provided valuable genetic and mechanistic insight, strategies that address study variability and lack of reproducibility are yet emerge. Nevertheless, with rapid growth and advancement in the field comes the promise of ever-evolving approaches that can aid in expanding the current understanding of the role of genetics in DR.

\section{Genome-Wide Association Studies (GWAS)}

Genome-wide association study (GWAS) approaches have enabled the identification of hundreds of genetic variants associated with complex diseases by the screening of single nucleotide polymorphisms (SNPs) across the complete genome for disease associations [70]. The first successful GWAS identified disease-associated SNPs in three independent studies of age-related macular degeneration (AMD) [71-73]. The success of these studies is commonly attributed to disease heritability, where heritability accounts for $50 \%$ of the genetic disease-associated variants in AMD [74,75]. However, this level of genetic heritability is not shared amongst other complex diseases, including DR. For example, Crohn's disease and Type 2 Diabetes can only be explained by $20 \%$ and $6 \%$ heritability, 
respectively $[76,77]$. Despite the case-to-case variability in heritability, GWAS has proven to be a powerful tool for the identification of SNPs in numerous complex diseases [78].

To date, GWAS has been used to identify DR-associated risk genes in various populations: Texan Mexican-Americans, American Caucasians, Taiwanese, Chinese, Japanese, and Australians (see Table 2) [79-85]. These studies have been extensively reviewed elsewhere $[55,56,86,87]$. Recently, GWAS identified genetic variation near the GRB2 gene (downstream of rs9896052, on chromosome 17q25.1) to be associated with sight-threatening DR [85]. To date, these results are the first to be confirmed with reproducible results in independent cohorts. Previously, all DR GWAS have yielded variable results and have lacked reproducibility. One possible explanation for the varying outcomes be the inconsistencies in definitions of DR and controls used in these studies. Additionally, a unique challenge of GWAS is that this method presents a high probability for false positives, due to the vast amount of genetic information yielded from whole-genome mapping. This can be problematic due to genetic variants identified using this method being often located on non-coding genetic regions of the genome [78]. Since it is believed non-coding regions do not offer functional relevance, [74] it is hypothesized that exome-focused approaches may yield a better understanding of genetic associations in DR.

Table 2. Genome-Wide Association Studies of Diabetic Retinopathy-associated Risk Genes in Various Populations.

\begin{tabular}{|c|c|c|c|c|}
\hline Study & Population & DR phenotype & Control & Identified Variants \\
\hline $\begin{array}{l}\text { Fu et al. } \\
\text { J Opthal } 2010 \text { [79] }\end{array}$ & $\begin{array}{l}\text { Mexican-American (Texas) } \\
\text { (T2D) }\end{array}$ & $\begin{array}{l}\text { Varying Severity of } \\
\text { NPDR and PDR }(n=103)\end{array}$ & $\begin{array}{l}\text { No DR-early NPDR; DM } 12 \\
\pm 9 \text { yrs } \\
(n=183)\end{array}$ & CAMK4 and FMN1 \\
\hline $\begin{array}{l}\text { Grassi et al. } \\
\text { Hum Mol Gen } 2011 \text { [80] }\end{array}$ & $\begin{array}{l}\text { American Caucasian from } \\
\text { GoKinD and EDIC studies } \\
\text { (T1D) }\end{array}$ & $\begin{array}{l}\text { focal laser treatment for } \\
\text { DME } \\
\text { panretinal photocoagulation } \\
\text { for PDR } \\
(n=973)\end{array}$ & $\begin{array}{l}\text { no laser treatment; } \\
\text { DM } 24 \pm 7 \text { yrs (GoKind), } 11 \\
\pm 4 \text { yrs (EDIC) } \\
(n=1856)\end{array}$ & $\begin{array}{l}\text { rs476141, rs227455, } \\
\text { CCDC101 }\end{array}$ \\
\hline $\begin{array}{l}\text { Huang et al. } \\
\text { Ophthalmology } 2011 \text { [81] }\end{array}$ & Taiwanese (T2D) & $\begin{array}{l}\text { NPDR }(n=102), \text { PDR } \\
(n=72)\end{array}$ & $\begin{array}{l}\text { No DR; DM } 8 \pm 6 \text { yrs } \\
(n=575)\end{array}$ & PLXDC2, ARHGAP22 \\
\hline $\begin{array}{l}\text { Sheu et al. } \\
\text { Hum Mol Gen } 2013 \text { [82] }\end{array}$ & $\begin{array}{l}\text { Taiwanese from Taiwan-US } \\
\text { Diabetic Retinopathy } \\
\text { (TUDR) } \\
\text { Study (T2D) }\end{array}$ & $\operatorname{PDR}(n=437)$ & No DR; DM $\geq 8$ yrs & $\begin{array}{l}\text { TBC1D4-COMMD6-UCHL3, } \\
\text { LRP2-BBS5, ARL4C-SH3BP4 }\end{array}$ \\
\hline $\begin{array}{l}\text { Lin et al. } \\
\text { Ophthalmologica } 2013 \text { [83] }\end{array}$ & Taiwanese (T2D) & $\begin{array}{l}\text { Varying Severity of } \\
\text { NPDR and PDR }(n=174)\end{array}$ & $\begin{array}{l}\text { No DR; DM 5-10 yrs } \\
(n=575)\end{array}$ & $\begin{array}{l}\text { rs10499298, rs10499299, } \\
\text { rs17827966, } \\
\text { rs1224329, rs1150790, } \\
\text { rs713050, } \\
\text { rs2518344 and rs487083; all } \\
\text { associated with } \\
\text { genes TMEM217, MRPL14 } \\
\text { and GRIK2 }\end{array}$ \\
\hline $\begin{array}{l}\text { Awata et al. } \\
\text { PLoS One } 2014 \text { [84] }\end{array}$ & Japanese (T2D) & $\begin{array}{l}\text { Varying Severity of } \\
\text { NPDR and PDR }(n=837)\end{array}$ & $\begin{array}{l}\text { No DR; DM } 7 \pm 6 \text { yrs } \\
(n=1149)\end{array}$ & rs9362054 \\
\hline $\begin{array}{l}\text { Burdon et al. } \\
\text { Diabetologia } 2015 \text { [85] }\end{array}$ & Australian (T2D) & $\begin{array}{l}\text { Sight-thretening DR } \\
\text { NPDR and PDR }(n=336)\end{array}$ & $\begin{array}{l}\text { No DR; DM } \geq 5 \text { yrs } \\
(n=508)\end{array}$ & $\begin{array}{l}\text { rs3805931, } \\
\text { rs9896052 (down stream of } \\
\text { GRB2 gene) }\end{array}$ \\
\hline
\end{tabular}

\section{Whole Exome Sequencing}

Whole exome sequencing (WES) methods rely on genome mapping specific to the protein coding (exome) regions [88]. Although exomes comprise only $\sim 1 \%$ of the human genome, it has been speculated that exomes harbor $\sim 85 \%$ of disease-associated variants [74]. Thus, WES has emerged as a novel and efficient method to identify gene variations that could help explain the role of genetics in complex diseases such as DR.

Recently, the WES approach has been used to identify the genetic variants associated with DR in two independent studies (see Table 3) $[89,90]$. Shtir and colleagues based their study on an 'extreme' phenotype design to search for 'protective' gene variants in a Saudi population, hypothesizing that using stringent criteria for study controls would enhance the probability to yield robust candidate variants [89]. Thus, individuals with 10 years duration of diabetes and no sign of retinopathy served as controls, while excluding those with high myopia, advanced glaucoma, and ocular ischemic syndrome, which have been previously shown to offer protection from DR. The DR phenotypes studied were 
NPDR and PDR with varying severity. Three genes were identified as protectant variants (NME3, LOC728699, and FASTK).

More recently, Ung and colleagues used a similar approach to analyze an African American (AA) Type 2 diabetic cohort from the African American Proliferative Diabetic Retinopathy Study and a mixed ethnicity (ME) cohort that included Type 1 and Type 2 diabetic participants of African American, Caucasian, and Hispanic backgrounds [90]. The DR phenotype under study was PDR and these cases were compared to the AA Type 2 diabetic control cohort which had a duration of diabetes for a minimum of 10 years. Together, AA and ME cohorts revealed a potential role of 25 novel variants in 19 genes associated with DR. Furthermore, expression-level validation studies demonstrated the potential role of six of the candidate genes identified to play a role in DR pathogenesis. However, one major drawback of this study was the use of the AA cohort as a control for both the AA and ME cohorts.

Table 3. Whole Exome Sequencing Studies of Diabetic Retinopathy.

\begin{tabular}{|c|c|c|c|c|}
\hline Study & Population & DR phenotype & Control & Identified Variants \\
\hline $\begin{array}{l}\text { Shtir et al. } \\
\text { Hum Genet } \\
2016 \text { [89] }\end{array}$ & $\begin{array}{l}\text { Saudi } \\
\text { (T1D and T2D) }\end{array}$ & $\begin{array}{l}\text { Varying Severity of } \\
\text { NPDR and PDR } \\
(n=43)\end{array}$ & $\begin{array}{l}\text { No DR, DM } 10 \text { yrs } \\
(n=64)\end{array}$ & NME3, LOC728699, FASTK \\
\hline \multicolumn{2}{|c|}{$\begin{array}{c}\text { Ung et al. } \\
\text { Vis Res } 2017 \text { [90] }\end{array}$} & $\operatorname{PDR}(n=57)$ & $\begin{array}{l}\text { No DR, DM } 10 \text { yrs } \\
(n=13)\end{array}$ & \\
\hline & $\begin{array}{l}\text { African American } \\
\text { (T2D) }\end{array}$ & & & $\begin{array}{l}\text { AKR1C3, KIAA1751, CD96, CRIPAK, } \\
\text { RGMA, } \\
\text { ZNF77, MPZL3, NLRP12, FAM92A1, } \\
\text { EFCAB3, } \\
\text { HNRNPCL1, SIGLEC11, ATP12A, } \\
\text { TMEM217, } \\
\text { FAM132A, SLC5A9 }\end{array}$ \\
\hline & $\begin{array}{l}\text { Mixed Ethnicity } \\
\text { (T1D and T2D) }\end{array}$ & & & $\begin{array}{l}\text { ABCA7, ABHD17A, ANO2, BPIFB6, } \\
\text { C15orf32, } \\
\text { CCDC105, CDKL1, CEP192, COL6A5, } \\
\text { CRIPAK, } \\
\text { DNHD1, GPATCH1, HMCN1, KIF24, } \\
\text { LRBA, LRB8, } \\
\text { MSH2, NAT1, PHF21A, PKHD1L1, } \\
\text { SLC6A13, } \\
\text { SLURP1, TTC22, UPK3A, VPS13B, } \\
\text { ZDHHC11B, } \\
\text { ZDHHC11, ZNF600 }\end{array}$ \\
\hline
\end{tabular}

To our knowledge, these have been the only DR WES studies to date. While both studies revealed novel DR-associated gene variants, these independent studies yielded variable results. The discrepancy of these results may be due to population heterogeneity and varying case definitions for DR phenotypes. However, one major limitation observed in these studies is the definition of controls with regards to no retinopathy despite 10 years of diabetes. As it may take up to 15 years to develop some features of DR, as shown in the WESDR study, controls with no DR should ideally be chosen from patients with a longer duration of diabetes (at least 20 years or longer). Despite the success in the identification of DR-associated variants, these studies must be replicated for meaningful biological conclusions and be further functionally validated. Nevertheless, these studies have provided valuable insight into the role of genetics in DR.

\section{Lessons Learned and Road Ahead}

At present, the genetic understanding of DR remains convoluted. Identifying the genetic factors responsible for DR has used traditional linkage analysis, candidate gene studies, GWAS, and WES analysis [42-45,50-54,57,79-85,89,90]. Out of three linkage studies done in Pima Indians and Mexican Americans, only one study showed a logarithm of odds score of 3.01 for single point and 2.58 for multiple-point analysis at 1p36 in Pima Indians. Additionally, association studies for numerous candidate genes, including VEGF, have yielded variable results [57]. The lack of overall success with the candidate gene studies includes failure to comprehensively identify variation in the genes of 
interest and incorrect hypotheses about which candidate genes are involved in the disease. Further, GWAS and WES studies for DR have also not produced any genome-wide statistically significant results $[79-85,89,90]$. These studies have lacked success due to (1) variability in case definitions that include examination of different DR case definitions including NPDR, PDR, and DME within and between studies, (2) inconsistently defined controls with regards to the duration of diabetes, and (3) population heterogeneity (e.g., discovery and replication samples coming from completely different ethnic populations). With such heterogeneity in phenotype definitions, let alone population heterogeneity, it is not surprising the findings have varied or have not been successful at all. If identified, the genetic factors that contribute to DR can be of added clinical value to determining a person's risk for DR. Thus, we have recently initiated a genomics study, the Diabetic Retinopathy Genetics (DRGen) Study, in efforts to address previous challenges, further understand the contribution of environmental factors on rare variants, responsiveness to anti-VEGF treatment, and determine if there are variants which protect against the initiation of DR.

\section{Diabetic Retinopathy Genetics (DRGen) Study Approach}

The DRGen Study is a collaboration of UNM School of Medicine and Harvard's Joslin Diabetes Center. Using a well-defined, clinically supported phenotypic strategy, we seek to better understand the role of rare variants in DR progression, or protection, and anti-VEGF response in DME. We propose for the first time a comprehensive genetic study of the genes and genetic variations involved in the inflammatory and angiogenesis pathways (Figure 1). Using whole exome sequencing (WES) technology, we aim test the coding region of all human genes for associations with DR. In addition to WES, all samples will be genotyped for ancestry informative markers for purposes related to admixture mapping.

Our interest lies in genes known to be involved in inflammatory and angiogenesis pathways, as both processes are known to play a role in DR pathology but have shown weak associations (in heterogeneous sample collections) with DR previously [91,92]. To date, two studies, as described above, utilized the WES technique in extreme DR phenotype patients. However, both studies used a very loose definition of the 'extreme' phenotype (i.e., no diabetic retinopathy despite at least 10 years of diabetes) $[89,90]$. The inclusion of participants with such a short duration of diabetes may lead to the misclassification of controls, given the results of Harvard's Joslin Medalist Study [7]. Thus, the DRGen study has an emphasis on the phenotypic heterogeneity of DR.

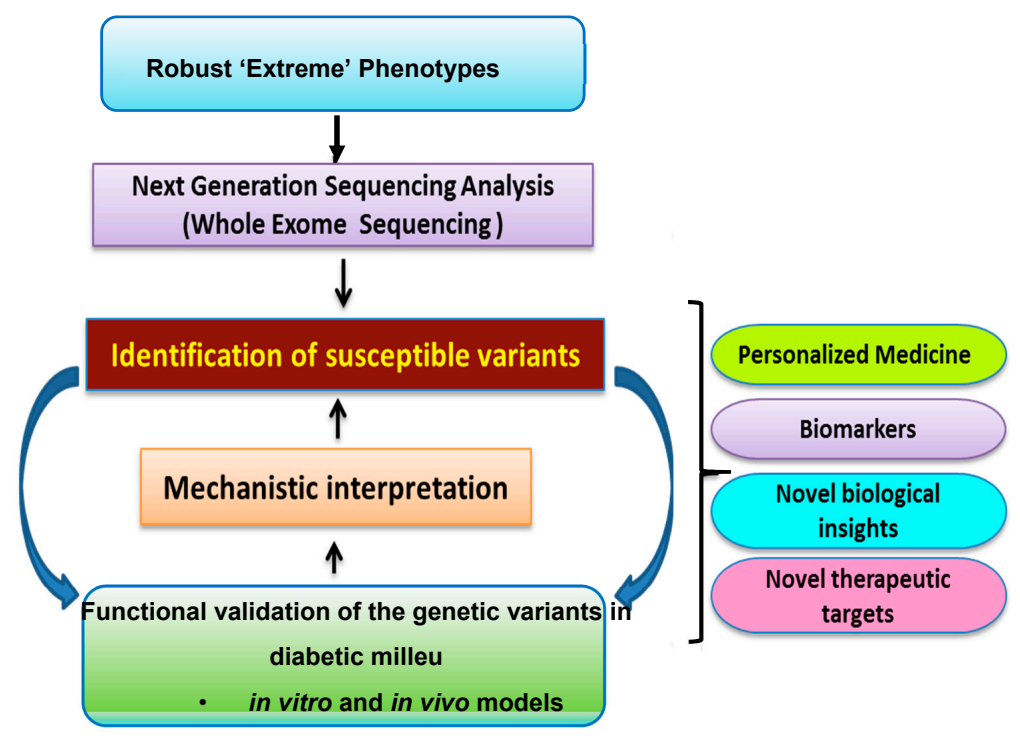

Figure 1. Schematic diagram of the experimental approach for characterizing genetic variants using next-generation sequencing (NGS). 


\section{Phenotypic Heterogeneity in DR}

After a period of no DR (clinical absence of vascular lesions in the retina) for a variable period of time (7-10 years), retinopathy develops. DR is classically divided into a non-proliferative (NPDR) or a proliferative (PDR) stage (Figure 2) $[6,93,94]$. The earliest clinical signs are microaneurysms, followed by dot and blot intraretinal hemorrhages. With the leakage of lipid (hard exudates) and plasma (edema), diabetic macular edema (DME) develops in some NPDR patients. Classically, the natural course of DR is thought to be no DR, mild-moderate NPDR, followed by PDR with longer duration of diabetes. However, DR appears to be a heterogenous disease, in which not every patient will go through the same sequence of events. Furthermore, not all diabetics develop DME or PDR [6]. New vessels grow in a subset of advanced DR patients, resulting in pre-retinal and vitreous hemorrhage, and eventually traction retinal detachment may occur in some patients. The WESDR Study has clearly shown that only about $50 \%$ of type 1 diabetics will develop PDR during their life time in spite of long durations of diabetes [8]. Currently, it is not known what protects the other $50 \%$ of diabetics from PDR.

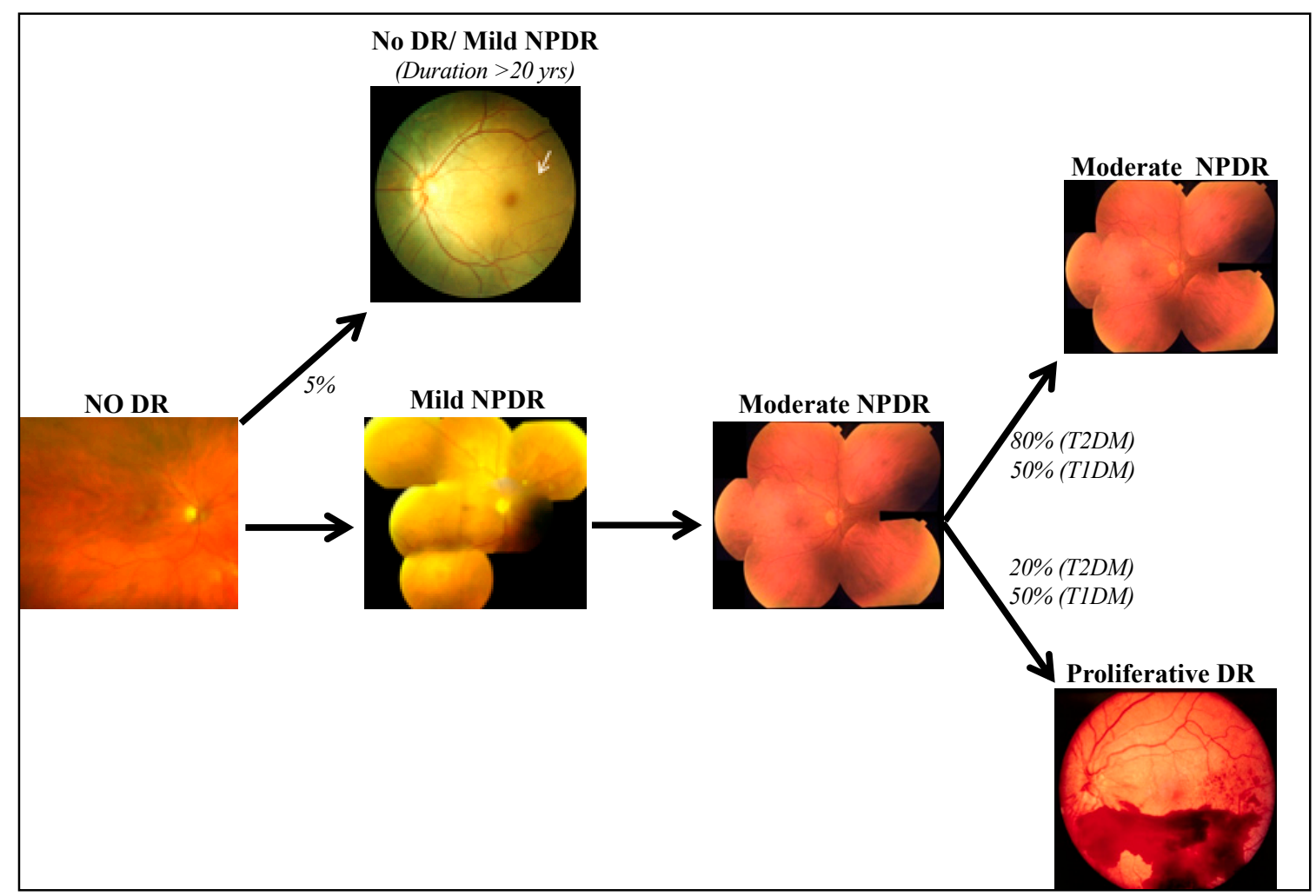

Figure 2. Based on our clinical observations and large epidemiological studies, the hypothesis proposed is that not every diabetic retinopathy (DR) patient goes through the same sequence of events. After a period of diabetes, patients can develop mild non-proliferative diabetic retinopathy (NPDR), followed by moderate NPDR. $20 \%$ of type 2 diabetes patients develop proliferative diabetic retinopathy (PDR) while $50 \%$ of type 1 diabetes patients develop PDR. In PDR patients, only $15 \%$ develop concurrent diabetic macular edema (DME), and the other $85 \%$ never develop any macular edema. Interestingly, $\sim 5 \%$ diabetic patients never develop DR or only have mild NPDR ( 1 or 2 microaneurysms, as indicated by white arrow), in spite of 20 or more years of diabetes ("Extreme Phenotype"). Images of mild NPDR and moderate NPDR phenotypes courtesy of the ETDRS Diabetic Retinopathy severity scale Ophthalmology (1991).

\section{1. 'Extreme' Phenotype}

Furthermore, some diabetics, despite long durations of diabetes (20 years or longer), do not show any sign of DR, or show minimal NPDR (a few microaneurysms). Harvard's Joslin Medalist Study 
reported this "extreme phenotype" in about $40 \%$ of their diabetics with a duration of 50 years diabetes or longer [7]. In fact, diabetics who did not develop advanced retinopathy over long durations of diabetes are unlikely to experience further worsening of retinopathy once they have had 17 or more years of follow-up. However, it is unknown what factors "protect" these patients from developing DR. Thus, the DRGen study aims to harmonize clinical data to reduce phenotypic heterogeneity; NPDR, PDR, and DME. Additionally, cases and controls will be defined consistently for the different samples studied. Important co-variates such as the duration of diabetes, hemoglobin A1C levels, and ancestry will also be included in the harmonization. Studying extreme phenotypes will further reduce issues related to phenotypic heterogeneity seen in previous studies.

\section{DME and PDR: Two Distinct Disease Processes}

Interestingly, our preliminary findings revealed that DME and PDR may be two distinctive disease processes [95]. In a retrospective cross-sectional study at UNM, we examined a sample of 165 eyes (majority Hispanics and Native Americans) with a new diagnosis of PDR with active neovascularization and 166 eyes with a new diagnosis of DME. Among the PDR eyes, only $15.7 \%$ of eyes (95\% CI 9.5-21.8\%) had DME by clinical examination or optical coherence tomography measurements of central retinal thickness (Figure 3). Thus, the majority of PDR patients did not have concurrent DME, leading us to ask: why do not all patients with PDR show concurrent vascular leakage (DME) in spite of high VEGF levels? Similarly, among the eyes with DME, only $20.3 \%$ of eyes (95\% CI 13.5-27.1\%) had concurrent PDR. Thus, the majority of DME patients did not have concurrent neovascularization or PDR. Stratified risk factor assessment demonstrated that neither gender, age, type of diabetes, $\mathrm{HbA1C}$, mean arterial pressure (MAP) nor LDL control were statistically significant in the development of DME in the PDR patients, or PDR in DME patients. Therefore, PDR and DME appear to represent two distinct disease processes of the same spectrum, possibly driven by distinctive molecular mediators and possibly distinct genetic factors (Figure 3).

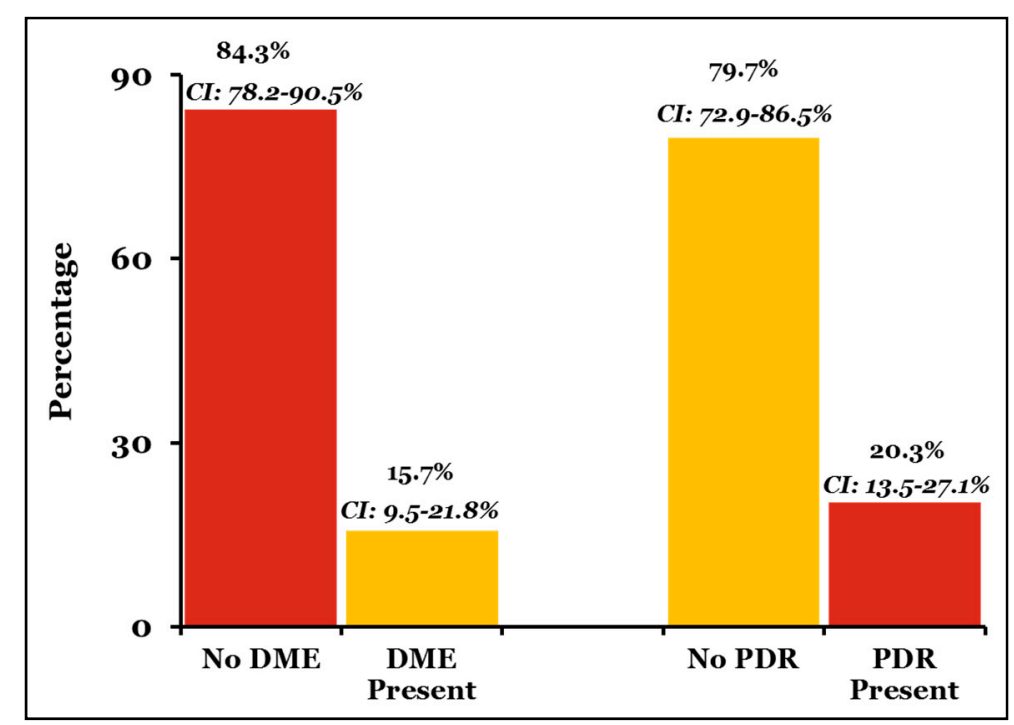

Figure 3. Based on a retrospective clinical study at the University of New Mexico, about $85 \%$ of proliferative diabetic retinopathy (PDR) patients do not have concurrent diabetic macular edema (DME), and, similarly, 80\% of DME patients do not have concurrent PDR. There is no influence of systemic factor control in such a correlation.

Furthermore, the response to anti-VEGF injections is variable in DME and PDR patients. New retinal vessels in PDR regress completely with one or two anti-VEGF injections in most patients [96], whereas such a robust effect is hardly seen in DME patients [97]. Interestingly, intravitreal anti-VEGF injection is the first line of treatment in DME patients, although the response is suboptimal in many. 
The variability in treatment responsiveness or differential efficacy of anti-VEGF drugs in DME and PDR suggests that there may be separate molecular pathways and genetic risk factors for the development of DME and PDR. To date, all three major clinical trials (DRCR, RIDE/RISE, VISTA) with anti-VEGF drugs have shown that only $27-45 \%$ of DME patients show three-line visual acuity improvement $[98,99]$. A post hoc analysis of the DRCR Protocol I data revealed that another 30-40\% of DME patients do not respond completely to anti-VEGF therapy [12]. Based on our preliminary findings and clinical evidence, we hypothesize that genetic factors may play a significant role in the susceptibility of DR, as well as in the response to anti-VEGF therapeutics. DME and PDR appear to be mediated by separate molecular mediators where inter-individual variation in responsiveness ("good responders" vs. "poor responders") to anti-VEGF therapy in DME may be attributable, in part, to genetic variants. Thus, this is suggestive that VEGF may be a good pharmacogenetic marker rather than a disease identifying variant.

\section{Admixture Mapping}

The heterogeneity in the populations studied previously may explain the lack of reproducibility of DR genetics studies. It is well known that DR, as with diabetes generally, varies across ethnicities $[100,101]$. Interestingly, studies of the same ethnic group have also failed to reproduce similar results. Previous studies have relied on self-reported ancestry, which could potentially be an issue if cases and controls are unintentionally pooled from different ethnic groups. If one of the cohorts has higher disease prevalence than the other, one will be overrepresented and the other underrepresented, potentially yielding a high probability of false-positive results $[102,103]$. Thus, to overcome this limitation, admixture mapping has been used to identify the genetic factors associated with a phenotype in heavily admixed populations [104]. Admixture-based association analyses rely on methods to quantify the degree of ancestry both across the genome as a whole and within defined genomic regions [105]. To overcome this challenge, the DRGen study will use Infinium Multi-Ethnic Global SNP Array, not necessarily to identify individuals by their ancestry, but rather to quantify degrees of admixture, in particular genomic regions that can then be correlated with a phenotype to identify chromosomal regions harboring variants likely to be associated with the DR phenotype [106].

\section{Preliminary Findings}

Using the aforementioned study design, two cohorts of patients were selected from the DRGen study population established at the UNM School of Medicine [107]. Briefly, we analyzed an 'extreme' phenotype cohort (no DR despite $>25$ years of diabetes; $n=6$ ) and an 'advanced' DR cohort (PDR within 15 years of diabetes; $n=6$ ). All subjects were matched for gender and age. After obtaining informed consent, DNA was isolated from white blood cells and WES was performed using the SureSelect All Human XT v5 exome kit, analyzed on the Illumina NovaSeq platform, followed by in-house downstream analysis pipeline to align the sequence reads and complete variant calling and annotation. We tested the enrichment of "risk" alleles in cases (PDR Group) with MAF $<0.05 \%$ and identified four heterozygous missense variants and a frame shift mutation in the PDR group. The analysis of rare coding variants revealed a novel set of genetic variants involved in the angiogenesis and inflammatory pathways that contribute to DR progression (KLF17, ZNF395, CD33, PLEKHG5, and COL18A1) or protection (NKX2.3). These variants are of particular interest, as KLF17 and ZNF395 have been postulated to promote the downstream activation of VEGF $[108,109]$. Similarly, CD33, a transmembrane receptor expressed on cells of myeloid lineage such as monocytes, has also been suggested to play a role in VEGF expression and inflammation [110]. Furthermore, PLEKHG5 is responsible for encoding a protein leading to NFKB1 signaling pathway activation, known to be involved in DR pathogenesis [111]. Additionally, it is well known that COL18A1 regulates the expression of endostatin, a potent endogenous angiogenesis inhibitor [112]. NKX2.3, a member of the NKX transcription factor family, has been shown to regulate genes involved in immune and inflammatory response, cell proliferation and angiogenesis [113]. While these variants have not been studied well in the context of DR, our preliminary analysis of mRNA isolated from human retinal 
endothelial cells treated with high glucose, has shown increased expression of COL18A, ZNF395, and PLEKHG5 $(p<0.0001)$. Further validation of these variants is necessary to confirm our findings. At present, the DRGen study is actively enrolling patients with selected DR phenotypes.

\section{Future Perspectives}

Although clinical evidence indicates that genetic factors are implicated in DR, their precise role remains elusive. We recognize that our preliminary findings represent the "tip of the iceberg" and therefore future plans include acquiring a larger study cohort and collecting additional biospecimens (blood and vitreous). Furthermore, we acknowledge that DR is not a homogenous phenotype, thus we will continue to harmonize the clinical data as described herein. The rare variant hypothesis represents the beginning of our vision of a comprehensive strategy involving clinical, genomic, and molecular data coupled with traditional statistical analyses and higher dimensional data analyses (e.g., deep learning). Furthermore, we hope to better understand the role of genetics in the variable anti-VEGF response observed in DME patients. We believe that the approach of harmonization of phenotypes and stringent patient cohort criteria, may lead to identification of novel genetics-based drug targets for DR. We recognize that the value of such results can help lead the forefront in personalized medicine that could potentially diagnose and help choose more efficacious treatments for patients. Immediate plans towards these future directions include creating a repository of blood samples with extracted genetic material and clinical phenotype information as a resource for the research community.

Author Contributions: Conceptualization, A.P.C. and A.D.; data curation, F.M., S.R., S.H., and P.M.; writing_-original draft preparation, A.P.C.; writing—review and editing, A.D., A.P.C., and F.M. All authors have read and agreed to the published version of the manuscript.

Funding: Supported by National Institutes of Health (NIH R01 EY 022327 R01 EY 028606-01-A1), VA Merit Review (I 01 BX 001801).

Acknowledgments: Supported by National Institutes of Health (NIH R01 EY 022327 R01 EY 028606-01-A1), VA Merit Review (I 01 BX 001801).

Conflicts of Interest: The authors declare no conflict of interest.

\section{References}

1. Wolter, J.R. Diabetic retinopathy. Am. J. Ophthalmol. 1961, 51, 1123-1141. [CrossRef]

2. Joussen, A.M.; Poulaki, V.; Le, M.L.; Koizumi, K.; Esser, C.; Janicki, H.; Schraermeyer, U.; Kociok, N.; Fauser, S.; Kirchhof, B.; et al. A central role for inflammation in the pathogenesis of diabetic retinopathy. FASEB J 2004, 18, 1450-1452. [CrossRef]

3. Cunha-Vaz, J.G. Studies on the pathophysiology of diabetic retinopathy. The blood-retinal barrier in diabetes. Diabetes 1983, 32, 20-27. [CrossRef]

4. Federation, I.D. IDF Diabetes Atlas. Diabetes Res. Clin. Pract. 2015, 109, 461-465.

5. Yau, J.W.; Rogers, S.L.; Kawasaki, R.; Lamoureux, E.L.; Kowalski, J.W.; Bek, T.; Chen, S.J.; Dekker, J.M.; Fletcher, A.; Grauslund, J.; et al. Global prevalence and major risk factors of diabetic retinopathy. Diabetes Care 2012, 35, 556-564. [CrossRef] [PubMed]

6. Das, A.; McGuire, P.G.; Rangasamy, S. Diabetic macular edema: Pathophysiology and novel therapeutic targets. Ophthalmology 2015, 122, 1375-1394. [CrossRef] [PubMed]

7. Sun, J.K.; Keenan, H.A.; Cavallerano, J.D.; Asztalos, B.F.; Schaefer, E.J.; Sell, D.R.; Strauch, C.M.; Monnier, V.M.; Doria, A.; Aiello, L.P.; et al. Protection from retinopathy and other complications in patients with type 1 diabetes of extreme duration: The joslin 50-year medalist study. Diabetes Care 2011, 34, 968-974. [CrossRef] [PubMed]

8. Klein, R.; Klein, B.E.; Moss, S.E.; Davis, M.D.; DeMets, D.L. The Wisconsin epidemiologic study of diabetic retinopathy. III. Prevalence and risk of diabetic retinopathy when age at diagnosis is 30 or more years. Arch. Ophthalmol. 1984, 102, 527-532. [CrossRef]

9. Lee, R.; Wong, T.Y.; Sabanayagam, C. Epidemiology of diabetic retinopathy, diabetic macular edema and related vision loss. Eye Vis. 2015, 2, 17. [CrossRef] 
10. Rangasamy, S.; McGuire, P.G.; Nitta, C.F.; Monickaraj, F.; Oruganti, S.R.; Das, A. Chemokine mediated monocyte trafficking into the retina: Role of inflammation in alteration of the blood-retinal barrier in diabetic retinopathy. PLoS ONE 2014, 9, e108508. [CrossRef]

11. Rangasamy, S.; McGuire, P.G.; Das, A. Diabetic retinopathy and inflammation: Novel therapeutic targets. Middle East Afr. J. Ophthalmol. 2012, 19, 52-59. [CrossRef] [PubMed]

12. Gonzalez, V.H.; Campbell, J.; Holekamp, N.M.; Kiss, S.; Loewenstein, A.; Augustin, A.J.; Ma, J.; Ho, A.C.; Patel, V.; Whitcup, S.M.; et al. Early and long-term responses to anti-vascular endothelial growth factor therapy in diabetic macular edema: Analysis of Protocol I Data. Am. J. Ophthalmol. 2016, 172, 72-79. [CrossRef] [PubMed]

13. Klein, R.; Klein, B.E.; Moss, S.E.; Davis, M.D.; DeMets, D.L. The Wisconsin epidemiologic study of diabetic retinopathy. II. Prevalence and risk of diabetic retinopathy when age at diagnosis is less than 30 years. Arch. Ophthalmol. 1984, 102, 520-526. [CrossRef] [PubMed]

14. Benarous, R.; Sasongko, M.B.; Qureshi, S.; Fenwick, E.; Dirani, M.; Wong, T.Y.; Lamoureux, E.L. Differential association of serum lipids with diabetic retinopathy and diabetic macular edema. Invest. Ophthalmol. Vis. Sci. 2011, 52, 7464-7469. [CrossRef] [PubMed]

15. King, P.; Peacock, I.; Donnelly, R. The UK prospective diabetes study (UKPDS): Clinical and therapeutic implications for type 2 diabetes. Br. J. Clin. Pharmacol. 1999, 48, 643-648. [CrossRef]

16. Diabetes Control and Complications Trial Research Group. The effect of intensive treatment of diabetes on the development and progression of long-term complications in insulin-dependent diabetes mellitus. $N$. Engl. J. Med. 1993, 329, 977-986. [CrossRef]

17. Chew, E.Y.; Klein, M.L.; Ferris, F.L.; Remaley, N.A.; Murphy, R.P.; Chantry, K.; Hoogwerf, B.J.; Miller, D. Association of elevated serum lipid levels with retinal hard exudate in diabetic retinopathy. Early Treatment Diabetic Retinopathy Study (ETDRS) Report 22. Arch. Ophthalmol. 1996, 114, 1079-1084. [CrossRef]

18. Keech, A.C.; Mitchell, P.; Summanen, P.A.; O’Day, J.; Davis, T.M.; Moffitt, M.S.; Taskinen, M.R.; Simes, R.J.; Tse, D.; Williamson, E.; et al. Effect of fenofibrate on the need for laser treatment for diabetic retinopathy (FIELD study): A randomised controlled trial. Lancet 2007, 370, 1687-1697. [CrossRef]

19. Beulens, J.W.J.; Patel, A.; Vingerling, J.R.; Cruickshank, J.K.; Hughes, A.D.; Stanton, A.; Lu, J.; Thom, S.M.; Grobbee, D.E.; Stolk, R.P. Effects of blood pressure lowering and intensive glucose control on the incidence and progression of retinopathy in patients with type 2 diabetes mellitus: A randomised controlled trial. Diabetologia 2009, 52, 2027-2036. [CrossRef]

20. ACCORD Study Group and ACCORD Eye Study Group. Effects of medical therapies on retinopathy progression in type 2 diabetes. N. Engl. J. Med. 2010, 363, 233-244. [CrossRef]

21. White, N.H.; Sun, W.; Cleary, P.A.; Tamborlane, W.V.; Danis, R.P.; Hainsworth, D.P.; Davis, M.D. DCCT-EDIC Research Group Effect of prior intensive therapy in type 1 diabetes on 10-year progression of retinopathy in the DCCT/EDIC: Comparison of adults and adolescents. Diabetes 2010, 59, 1244-1253. [CrossRef]

22. Klein, R.; Klein, B.E.; Moss, S.E.; Cruickshanks, K.J. The wisconsin epidemiologic study of diabetic retinopathy: XVII. The 14-year incidence and progression of diabetic retinopathy and associated risk factors in type 1 diabetes. Ophthalmology 1998, 105, 1801-1815. [CrossRef]

23. Lachin, J.M.; Genuth, S.; Nathan, D.M.; Zinman, B.; Rutledge, B.N. Effect of glycemic exposure on the risk of microvascular complications in the diabetes control and complications trial-Revisited. Diabetes 2008, 57, 995-1001. [CrossRef]

24. Brownlee, M. The pathobiology of diabetic complications: A unifying mechanism. Diabetes 2005, 54, 1615-1625. [CrossRef]

25. Kavvoura, F.K.; Ioannidis, J.P. Methods for meta-analysis in genetic association studies: A review of their potential and pitfalls. Hum. Genet. 2008, 123, 1-14. [CrossRef]

26. Lowe, W.L., Jr.; Reddy, T.E. Genomic approaches for understanding the genetics of complex disease. Genome Res. 2015, 25, 1432-1441. [CrossRef]

27. Wang, K.; Bucan, M.; Grant, S.F.; Schellenberg, G.; Hakonarson, H. Strategies for genetic studies of complex diseases. Cell 2010, 142, 351-353. [CrossRef] [PubMed]

28. Leslie, R.D.; Pyke, D.A. Diabetic retinopathy in identical twins. Diabetes 1982, 31, 19-21. [CrossRef] [PubMed]

29. Pyke, D.A.; Tattersall, R.B. Diabetic retinopathy in identical twins. Diabetes 1973, 22, 613-618. [CrossRef] [PubMed] 
30. Clustering of long-term complications in families with diabetes in the diabetes control and complications trial. The Diabetes Control and Complications Trial Research Group. Diabetes 1997, 46, 1829-1839.

31. Wong, T.Y.; Klein, R.; Islam, F.A.; Cotch, M.F.; Folsom, A.R.; Klein, B.E.; Sharrett, A.R.; Shea, S.; Multi-Ethnic Study of Atherosclerosis (MESA). Diabetic retinopathy in a multi-ethnic cohort in the United States. Am. J. Ophthalmol. 2006, 141, 446-455. [CrossRef] [PubMed]

32. Harris, M.I.; Klein, R.; Cowie, C.C.; Rowland, M.; Byrd-Holt, D.D. Is the risk of diabetic retinopathy greater in non-Hispanic blacks and Mexican Americans than in non-Hispanic whites with type 2 diabetes? A U.S. population study. Diabetes Care 1998, 21, 1230-1235. [CrossRef] [PubMed]

33. Haffner, S.M.; Fong, D.; Stern, M.P.; Pugh, J.A.; Hazuda, H.P.; Patterson, J.K.; Van Heuven, W.A.J.; Klein, R. Diabetic retinopathy in Mexican Americans and non-Hispanic whites. Diabetes 1988, 37, 878-884. [CrossRef] [PubMed]

34. Service, S.K.; Ophoff, R.A.; Freimer, N.B. The genome-wide distribution of background linkage disequilibrium in a population isolate. Hum. Mol. Genet. 2001, 10, 545-551. [CrossRef]

35. Cardon, L.R.; Bell, J.I. Association study designs for complex diseases. Nat. Rev. Genet. 2001, 2, 91-99. [CrossRef]

36. Kruglyak, L. Prospects for whole-genome linkage disequilibrium mapping of common disease genes. Nat. Genet. 1999, 22, 139-144. [CrossRef]

37. Terwilliger, J.D.; Goring, H.H. Gene mapping in the 20th and 21st centuries: Statistical methods, data analysis, and experimental design. Hum. Biol. 2000, 72, 63-132. [CrossRef]

38. Rao, D.C. Genetic dissection of complex traits: An overview. Adv. Genet. 2001, 42, 13-34.

39. Duncan, E.; Brown, M.; Shore, E.M. The revolution in human monogenic disease mapping. Genes 2014, 5, 792-803. [CrossRef]

40. Newton-Cheh, C.; Hirschhorn, J.N. Genetic association studies of complex traits: Design and analysis issues. Mutat. Res. 2005, 573, 54-69. [CrossRef]

41. Altmuller, J.; Palmer, L.J.; Fischer, G.; Scherb, H.; Wjst, M. Genomewide scans of complex human diseases: True linkage is hard to find. Am. J. Hum. Genet. 2001, 69, 936-950. [CrossRef] [PubMed]

42. Looker, H.C.; Nelson, R.G.; Chew, E.; Klein, R.; Klein, B.E.; Knowler, W.C.; Hanson, R.L. Genome-wide linkage analyses to identify Loci for diabetic retinopathy. Diabetes 2007, 56, 1160-1166. [CrossRef] [PubMed]

43. Imperatore, G.; Hanson, R.L.; Pettitt, D.J.; Kobes, S.; Bennett, P.H.; Knowler, W.C. Sib-pair linkage analysis for susceptibility genes for microvascular complications among Pima Indians with type 2 diabetes. Pima Diabetes Genes Group. Diabetes 1998, 47, 821-830. [CrossRef] [PubMed]

44. Hallman, D.M.; Boerwinkle, E.; Gonzalez, V.H.; Klein, B.E.; Klein, R.; Hanis, C.L. A genome-wide linkage scan for diabetic retinopathy susceptibility genes in Mexican Americans with type 2 diabetes from Starr County, Texas. Diabetes 2007, 56, 1167-1173. [CrossRef]

45. Dyck, P.J.; Kratz, K.M.; Karnes, J.L.; Litchy, W.J.; Klein, R.; Pach, J.M.; Wilson, D.M.; O’brien, P.C.; Melton, L. The prevalence by staged severity of various types of diabetic neuropathy, retinopathy, and nephropathy in a population-based cohort: The Rochester Diabetic Neuropathy Study. Neurology 1993, 43, 817-824. [CrossRef]

46. Nathan, D.M. Long-term complications of diabetes mellitus. N. Engl. J. Med. 1993, 328, 1676-1685. [CrossRef]

47. Zhu, M.; Zhao, S. Candidate gene identification approach: Progress and challenges. Int. J. Biol. Sci. 2007, 3, 420-427. [CrossRef]

48. Jorgensen, T.J.; Ruczinski, I.; Kessing, B.; Smith, M.W.; Shugart, Y.Y.; Alberg, A.J. Hypothesis-driven candidate gene association studies: Practical design and analytical considerations. Am. J. Epidemiol. 2009, 170, 986-993. [CrossRef]

49. Tabor, H.K.; Risch, N.J.; Myers, R.M. Candidate-gene approaches for studying complex genetic traits: Practical considerations. Nat. Rev. Genet. 2002, 3, 391-397. [CrossRef]

50. Abhary, S.; Burdon, K.P.; Gupta, A.; Lake, S.; Selva, D.; Petrovsky, N.; Craig, J.E. Common sequence variation in the VEGFA gene predicts risk of diabetic retinopathy. Invest. Ophthalmol. Vis. Sci. 2009, 50, 5552-5558. [CrossRef]

51. Abhary, S.; Hewitt, A.W.; Burdon, K.P.; Craig, J.E. A systematic meta-analysis of genetic association studies for diabetic retinopathy. Diabetes 2009, 58, 2137-2147. [CrossRef] [PubMed]

52. Balasubbu, S.; Sundaresan, P.; Rajendran, A.; Ramasamy, K.; Govindarajan, G.; Perumalsamy, N.; Hejtmancik, J.F. Association analysis of nine candidate gene polymorphisms in Indian patients with type 2 diabetic retinopathy. BMC Med. Genet. 2010, 11, 158. [CrossRef] [PubMed] 
53. Li, H.; Louey, J.W.; Choy, K.W.; Liu, D.T.; Chan, W.M.; Chan, Y.M.; Fung, N.S.; Fan, B.J.; Baum, L.; Chan, J.C.; et al. EDN1 Lys198Asn is associated with diabetic retinopathy in type 2 diabetes. Mol. Vis. 2008, 14, 1698-1704. [PubMed]

54. Liang, S.; Pan, M.; Hu, N.; Wu, Y.Y.; Chen, H.; Zhu, J.H.; Guan, H.J.; Sang, A.M. Association of angiotensin-converting enzyme gene $2350 \mathrm{G} / \mathrm{A}$ polymorphism with diabetic retinopathy in Chinese Han population. Mol. Biol. Rep. 2013, 40, 463-468. [CrossRef] [PubMed]

55. Cho, H.; Sobrin, L. Genetics of diabetic retinopathy. Curr. Diab. Rep. 2014, 14, 515. [CrossRef] [PubMed]

56. Kuo, J.Z.; Wong, T.Y.; Rotter, J.I. Challenges in elucidating the genetics of diabetic retinopathy. JAMA Ophthalmol. 2014, 132, 96-107. [CrossRef]

57. Sobrin, L.; Green, T.; Sim, X.; Jensen, R.A.; Tai, E.S.; Tay, W.T.; Wang, J.J.; Mitchell, P.; Sandholm, N.; Liu, Y.; et al. Candidate gene association study for diabetic retinopathy in persons with type 2 diabetes: The Candidate gene Association Resource (CARe). Invest. Ophthalmol. Vis. Sci. 2011, 52, 7593-7602. [CrossRef]

58. Miller, J.W.; Adamis, A.P.; Shima, D.T.; D’Amore, P.A.; Moulton, R.S.; O’Reilly, M.S.; Folkman, J.; Dvorak, H.F.; Brown, L.F.; Berse, B.; et al. Vascular endothelial growth factor/vascular permeability factor is temporally and spatially correlated with ocular angiogenesis in a primate model. Am. J. Pathol. 1994, 145, 574-584. [CrossRef]

59. Kim, L.A.; D'Amore, P.A. A brief history of anti-VEGF for the treatment of ocular angiogenesis. Am. J. Pathol. 2012, 181, 376-379. [CrossRef]

60. Aiello, L.P.; Avery, R.L.; Arrigg, P.G.; Keyt, B.A.; Jampel, H.D.; Shah, S.T.; Pasquale, L.R.; Thieme, H.; Iwamoto, M.A.; Park, J.E.; et al. Vascular endothelial growth factor in ocular fluid of patients with diabetic retinopathy and other retinal disorders. N. Engl. J. Med. 1994, 331, 1480-1487. [CrossRef]

61. Churchill, A.J.; Carter, J.G.; Ramsden, C.; Turner, S.J.; Yeung, A.; Brenchley, P.E.; Ray, D.W. VEGF polymorphisms are associated with severity of diabetic retinopathy. Invest. Ophthalmol. Vis. Sci. 2008, 49, 3611-3616. [CrossRef] [PubMed]

62. Nakanishi, K.; Watanabe, C. Single nucleotide polymorphisms of vascular endothelial growth factor gene intron 2 are markers for early progression of diabetic retinopathy in Japanese with type 1 diabetes. Clin. Chim. Acta 2009, 402, 171-175. [CrossRef] [PubMed]

63. Liew, G.; Klein, R.; Wong, T.Y. The role of genetics in susceptibility to diabetic retinopathy. Int. Ophthalmol. Clin. 2009, 49, 35-52. [CrossRef] [PubMed]

64. Gordon, M.S.; Margolin, K.; Talpaz, M.; Sledge Jr, G.W.; Holmgren, E.; Benjamin, R.; Stalter, S.; Shak, S.; Adelman, D.C. Phase I safety and pharmacokinetic study of recombinant human anti-vascular endothelial growth factor in patients with advanced cancer. J. Clin. Oncol. 2001, 19, 843-850. [CrossRef]

65. Jampol, L.M.; Bressler, N.M.; Glassman, A.R. Revolution to a new standard treatment of diabetic macular edema. JAMA 2014, 311, 2269-2270. [CrossRef]

66. El-Shazly, S.F.; El-Bradey, M.H.; Tameesh, M.K. Vascular endothelial growth factor gene polymorphism prevalence in patients with diabetic macular oedema and its correlation with anti-vascular endothelial growth factor treatment outcomes. Clin. Exp. Ophthalmol. 2014, 42, 369-378. [CrossRef]

67. Suganthalakshmi, B.; Anand, R.; Kim, R.; Mahalakshmi, R.; Karthikprakash, S.; Namperumalsamy, P.; Sundaresan, P. Association of VEGF and eNOS gene polymorphisms in type 2 diabetic retinopathy. Mol. Vis. 2006, 12, 336-341.

68. Petrovič, M.G.; Korošec, P.; Košnik, M.; Osredkar, J.; Hawlina, M.; Peterlin, B.; Petrovič, D. Local and genetic determinants of vascular endothelial growth factor expression in advanced proliferative diabetic retinopathy. Mol. Vis. 2008, 14, 1382-1387.

69. Awata, T.; Kurihara, S.; Takata, N.; Neda, T.; Iizuka, H.; Ohkubo, T.; Osaki, M.; Watanabe, M.; Nakashima, Y.; Inukai, K.; et al. Functional VEGF C-634G polymorphism is associated with development of diabetic macular edema and correlated with macular retinal thickness in type 2 diabetes. Biochem. Biophys. Res. Commun. 2005, 333, 679-685. [CrossRef]

70. Chandra, A.; Mitry, D.; Wright, A.; Campbell, H.; Charteris, D.G. Genome-wide association studies: Applications and insights gained in Ophthalmology. Eye 2014, 28, 1066-1079. [CrossRef]

71. Klein, R.J.; Zeiss, C.; Chew, E.Y.; Tsai, J.Y.; Sackler, R.S.; Haynes, C.; Henning, A.K.; SanGiovanni, J.P.; Mane, S.M.; Mayne, S.T.; et al. Complement factor H polymorphism in age-related macular degeneration. Science 2005, 308, 385-389. [CrossRef] [PubMed] 
72. Haines, J.L.; Hauser, M.A.; Schmidt, S.; Scott, W.K.; Olson, L.M.; Gallins, P.; Spencer, K.L.; Kwan, S.Y.; Noureddine, M.; Gilbert, J.R.; et al. Complement factor $\mathrm{H}$ variant increases the risk of age-related macular degeneration. Science 2005, 308, 419-421. [CrossRef] [PubMed]

73. Edwards, A.O.; Ritter, R.; Abel, K.J.; Manning, A.; Panhuysen, C.; Farrer, L.A. Complement factor H polymorphism and age-related macular degeneration. Science 2005, 308, 421-424. [CrossRef] [PubMed]

74. Manolio, T.A.; Collins, F.S.; Cox, N.J.; Goldstein, D.B.; Hindorff, L.A.; Hunter, D.J.; McCarthy, M.I.; Ramos, E.M.; Cardon, L.R.; Chakravarti, A.; et al. Finding the missing heritability of complex diseases. Nature 2009, 461, 747-753. [CrossRef]

75. Maller, J.; George, S.; Purcell, S.; Fagerness, J.; Altshuler, D.; Daly, M.J.; Seddon, J.M. Common variation in three genes, including a noncoding variant in $\mathrm{CFH}$, strongly influences risk of age-related macular degeneration. Nat. Genet. 2006, 38, 1055-1059. [CrossRef]

76. Zeggini, E.; Scott, L.J.; Saxena, R.; Voight, B.F.; Marchini, J.L.; Hu, T.; de Bakker, P.I.; Abecasis, G.R.; Almgren, P.; Andersen, G.; et al. Meta-analysis of genome-wide association data and large-scale replication identifies additional susceptibility loci for type 2 diabetes. Nat. Genet. 2008, 40, 638-645. [CrossRef]

77. Barrett, J.C.; Hansoul, S.; Nicolae, D.L.; Cho, J.H.; Duerr, R.H.; Rioux, J.D.; Brant, S.R.; Silverberg, M.S.; Taylor, K.D.; Barmada, M.M.; et al. Genome-wide association defines more than 30 distinct susceptibility loci for Crohn's disease. Nat. Genet. 2008, 40, 955-962. [CrossRef]

78. Hindorff, L.A.; Sethupathy, P.; Junkins, H.A.; Ramos, E.M.; Mehta, J.P.; Collins, F.S.; Manolio, T.A. Potential etiologic and functional implications of genome-wide association loci for human diseases and traits. Proc. Natl. Acad. Sci. USA 2009, 106, 9362-9367. [CrossRef]

79. Fu, Y.P.; Hallman, D.M.; Gonzalez, V.H.; Klein, B.E.; Klein, R.; Hayes, M.G.; Cox, N.J.; Bell, G.I.; Hanis, C.L. Identification of diabetic retinopathy genes through a genome-wide association study among Mexican-Americans from Starr County, Texas. J. Ophthalmol. 2010. [CrossRef]

80. Grassi, M.A.; Tikhomirov, A.; Ramalingam, S.; Below, J.E.; Cox, N.J.; Nicolae, D.L. Genome-wide meta-analysis for severe diabetic retinopathy. Hum. Mol. Genet. 2011, 20, 2472-2481. [CrossRef]

81. Huang, Y.C.; Lin, J.M.; Lin, H.J.; Chen, C.C.; Chen, S.Y.; Tsai, C.H.; Tsai, F.J. Genome-wide association study of diabetic retinopathy in a Taiwanese population. Ophthalmology 2011, 118, 642-648. [CrossRef] [PubMed]

82. Sheu, W.H.H.; Kuo, J.Z.; Lee, I.T.; Hung, Y.J.; Lee, W.J.; Tsai, H.Y.; Wang, J.S.; Goodarzi, M.O.; Klein, R.; Klein, B.E.; et al. Genome-wide association study in a Chinese population with diabetic retinopathy. Hum. Mol. Genet. 2013, 22, 3165-3173. [CrossRef] [PubMed]

83. Lin, H.J.; Huang, Y.C.; Lin, J.M.; Wu, J.Y.; Chen, L.A.; Tsai, F.J. Association of genes on chromosome 6, GRIK2, TMEM217 and TMEM63B (linked to MRPL14 ) with diabetic retinopathy. Ophthalmologica 2013, 229, 54-60. [CrossRef]

84. Awata, T.; Yamashita, H.; Kurihara, S.; Morita-Ohkubo, T.; Miyashita, Y.; Katayama, S.; Mori, K.; Yoneya, S.; Kohda, M.; Okazaki, Y.; et al. Correction: A genome-wide association study for diabetic retinopathy in a Japanese population: Potential association with a long intergenic non-coding RNA. PLoS ONE 2015, 10, e0126789. [CrossRef]

85. Burdon, K.P.; Fogarty, R.D.; Shen, W.; Abhary, S.; Kaidonis, G.; Appukuttan, B.; Hewitt, A.W.; Sharma, S.; Daniell, M.; Essex, R.W.; et al. Genome-wide association study for sight-threatening diabetic retinopathy reveals association with genetic variation near the GRB2 gene. Diabetologia 2015, 58, 2288-2297. [CrossRef]

86. Mishra, B.; Swaroop, A.; Kandpal, R.P. Genetic components in diabetic retinopathy. Indian J. Ophthalmol. 2016, 64, 55-61. [CrossRef]

87. Lisa Tom, S.D.; Sobrin, L. Genetic epidemiology of diabetic retinopathy. Ann. Eye Sci. 2017, 2. [CrossRef]

88. Warr, A.; Robert, C.; Hume, D.; Archibald, A.; Deeb, N.; Watson, M. Exome sequencing: Current and future perspectives. G3 Genes Genomes Genet. 2015, 5, 1543-1550. [CrossRef]

89. Shtir, C.; Aldahmesh, M.A.; Al-Dahmash, S.; Abboud, E.; Alkuraya, H.; Abouammoh, M.A.; Nowailaty, S.R.; Al-Thubaiti, G.; Naim, E.A.; ALYounes, B.; et al. Exome-based case-control association study using extreme phenotype design reveals novel candidates with protective effect in diabetic retinopathy. Hum. Genet. 2016, 135, 193-200. [CrossRef]

90. Ung, C.; Sanchez, A.V.; Shen, L.; Davoudi, S.; Ahmadi, T.; Navarro-Gomez, D.; Chen, C.J.; Hancock, H.; Penman, A.; Hoadley, S.; et al. Whole exome sequencing identification of novel candidate genes in patients with proliferative diabetic retinopathy. Vis. Res. 2017, 139, 168-176. [CrossRef] 
91. Loza, M.J.; McCall, C.E.; Li, L.; Isaacs, W.B.; Xu, J.; Chang, B.L. Assembly of inflammation-related genes for pathway-focused genetic analysis. PLOS ONE 2007, 2, e1035. [CrossRef] [PubMed]

92. Kunz, M.; Moeller, S.; Koczan, D.; Lorenz, P.; Wenger, R.H.; Glocker, M.O.; Thiesen, H.J.; Gross, G.; Ibrahim, S.M. Mechanisms of hypoxic gene regulation of angiogenesis factor Cyr61 in melanoma cells. J. Biol. Chem. 2003, 278, 45651-45660. [CrossRef] [PubMed]

93. Hartnett, M.E.; Baehr, W.; Le, Y.Z. Diabetic retinopathy, an overview. Vis. Res. 2017, 139, 1-6. [CrossRef] [PubMed]

94. Frank, R.N. Diabetic retinopathy. N. Engl. J. Med. 2004, 350, 48-58. [CrossRef] [PubMed]

95. Hobbs, S.M.A.; Patel, A.; Das, A. Proliferative Diabetic Retinopathy and Diabetic Macular Edema: Are These Two Different Disease Processes; A Retrospective Cross-sectional Study. Investig. Ophthalmol. Visual Sci. 2016, 57, 1592.

96. Avery, R.L.; Pearlman, J.; Pieramici, D.J.; Rabena, M.D.; Castellarin, A.A.; Ma'an, A.N.; Giust, M.J.; Wendel, R.; Patel, A. Intravitreal bevacizumab (Avastin) in the treatment of proliferative diabetic retinopathy. Ophthalmology 2006, 113, 1695-1705. [CrossRef]

97. Frank, R.N. Diabetic Retinopathy: Where Are We and a Path to Progress; The Lasker/IRRF Initiative for Innovation in Vision Science: New York, NY, USA, 2012.

98. Korobelnik, J.F.; Do, D.V.; Schmidt-Erfurth, U.; Boyer, D.S.; Holz, F.G.; Heier, J.S.; Midena, E.; Kaiser, P.K.; Terasaki, H.; Nguyen, Q.D.; et al. Intravitreal aflibercept for diabetic macular edema. Ophthalmology 2014, 121, 2247-2254. [CrossRef]

99. Elman, M.J.; Aiello, L.P.; Beck, R.W.; Bressler, N.M.; Bressler, S.B.; Edwards, A.R.; Ferris III, F.L.; Friedman, S.M.; Glassman, A.R.; Miller, K.M.; et al. Randomized trial evaluating ranibizumab plus prompt or deferred laser or triamcinolone plus prompt laser for diabetic macular edema. Ophthalmology 2010, 117, 1064-1077. [CrossRef]

100. Scanlon, P.H.; Aldington, S.J.; Stratton, I.M. Epidemiological issues in diabetic retinopathy. Middle East Afr. J. Ophthalmol. 2013, 20, 293-300. [CrossRef]

101. Lander, E.; Kruglyak, L. Genetic dissection of complex traits: Guidelines for interpreting and reporting linkage results. Nat. Genet. 1995, 11, 241-247. [CrossRef]

102. Shriner, D. Overview of admixture mapping. Curr. Protoc. Hum. Genet. 2017, 94, 1-23. [CrossRef] [PubMed]

103. Hellwege, J.N.; Keaton, J.M.; Giri, A.; Gao, X.; Velez Edwards, D.R.; Edwards, T.L. Population stratification in genetic association studies. Curr. Protoc. Hum. Genet. 2017, 95, 1-22. [CrossRef] [PubMed]

104. Libiger, O.; Schork, N.J. A method for inferring an individual's genetic ancestry and degree of admixture associated with six major continental populations. Front. Genet. 2012, 3, 322. [CrossRef]

105. Kowluru, R.A. Diabetic retinopathy, metabolic memory and epigenetic modifications. Vis. Res. 2017, 139, 30-38. [CrossRef]

106. Goetz, L.H.; Uribe-Bruce, L.; Quarless, D.; Libiger, O.; Schork, N.J. Admixture and clinical phenotypic variation. Hum. Hered. 2014, 77, 73-86. [CrossRef]

107. Das, A.; Rangasamy, S.; Naymik, M.; Monickaraj, F.; Legendre, C.; Balak, C.; Duggan, D.; Schork, N.; McGuire, P. Novel genetic variants in extreme phenotypes of diabetic retinopathy: DRGen Study. IOVS 2018, $59,1911$.

108. Iwanicki, M.P.; Brugge, J.S. Transcriptional regulation of metastatic [Id]entity by KLF17. Genome Biol. 2009, 10, 244. [CrossRef]

109. Murat, A.; Migliavacca, E.; Hussain, S.F.; Heimberger, A.B.; Desbaillets, I.; Hamou, M.F.; Rüegg, C.; Stupp, R.; Delorenzi, M.; Hegi, M.E. Modulation of angiogenic and inflammatory response in glioblastoma by hypoxia. PLoS ONE 2009, 4, e5947. [CrossRef]

110. Horikawa, N.; Abiko, K.; Matsumura, N.; Hamanishi, J.; Baba, T.; Yamaguchi, K.; Yoshioka, Y.; Koshiyama, M.; Konishi, I. Expression of vascular endothelial growth factor in ovarian cancer inhibits tumor immunity through the accumulation of myeloid-derived suppressor cells. Clin. Cancer Res. 2017, 23, 587-599. [CrossRef]

111. Maystadt, I.; Rezsöhazy, R.; Barkats, M.; Duque, S.; Vannuffel, P.; Remacle, S.; Lambert, B.; Najimi, M.; Sokal, E.; Munnich, A.; et al. The nuclear factor kappaB-activator gene PLEKHG5 is mutated in a form of autosomal recessive lower motor neuron disease with childhood onset. Am. J. Hum. Genet. 2007, 81, 67-76. [CrossRef] 
112. O'Reilly, M.S.; Boehm, T.; Shing, Y.; Fukai, N.; Vasios, G.; Lane, W.S.; Flynn, E.; Birkhead, J.R.; Olsen, B.R.; Folkman, J. Endostatin: An endogenous inhibitor of angiogenesis and tumor growth. Cell 1997, 88, $277-285$. [CrossRef]

113. Yu, W.; Hegarty, J.P.; Berg, A.; Chen, X.; West, G.; Kelly, A.A.; Wang, Y.; Poritz, L.S.; Koltun, W.A.; Lin, Z. NKX2-3 transcriptional regulation of endothelin-1 and VEGF signaling in human intestinal microvascular endothelial cells. PLoS ONE 2011, 6, e20454. [CrossRef] [PubMed] 